\title{
Effect of Cycloheximide and Actinomycin D on the Dietary Induction of Intestinal Brush Border Enzyme Activities of Rats
}

\author{
Motoni Kadowaki, Akio Takenaka, Yeon Sook Lee \\ and Hiroshi NaITo \\ Department of Agricultural Chemistry, Faculty of Agriculture, \\ The University of Tokyo, Tokyo 113, Japan \\ Received December 18, 1978
}

\begin{abstract}
The activities of intestinal alkaline phosphatase [E.C. 3.1.3.1.], sucrase ( $\beta$-D-fructofranoside fructohydrolase) [E.C. 3.2.1.26.] and leucine $p$-nitroanilidase [E.C. 3.4.11.2.] were equally enhanced within $4 \mathrm{hr}$ after single feeding of egg albumin to 4-day starved rats. They were maintained at the induced levels up to $12 \mathrm{hr}$, followed by a gradual decrease. Single feeding of sucrose did not affect sucrase activity within $8 \mathrm{hr}$, but gradually raised it later than $12 \mathrm{hr}$.

The injection of cycloheximide diminished these dietary induction of enzyme activities to the levels in starvation. In starved controls, only sucrase activity was inhibited by actinomycin $\mathrm{D}$ whose dose inhibited the incorporation of ${ }^{3} \mathrm{H}$-uridine into the mucosal homogenate. However, in feeding rats, the same dose of actinomycin $\mathrm{D}$ decreased all the induced enzyme activities below the levels in starvation without inhibiting the incorporation of ${ }^{3} \mathrm{H}$-uridine.

The effect of dietary protein on brush border enzymes seemed to be little in germ-free rats as compared with conventional animals.
\end{abstract}

Previously we reported that alkaline phosphatase activity in the rat small intestine was increased within a few hours after single feeding of various food proteins, which was not specifically related to a dietary phosphoprotein such as casein or whole egg protein. ${ }^{1)}$

In the present study, other enzymes, sucrase and leucine $p$-nitroanilidase, were selected to verify whether they underwent similar control mechanism by dietary substances, since these enzymes are known to locate together closely in brush border of mucosal cells. ${ }^{2)}$ To evaluate this mechanism, in most studies published have been dealt with the feeding experiments for relatively long period with a mixed diet, which may implicate too many factors to be explained. Experiments were therefore performed within a day after single feeding of protein or sucrose to 4-day starved rats, during whose period circadian rhythms of most enzymes seem to disappear. ${ }^{3}$.

Part of this work was presented at the Annual Meeting of the Agricultural Chemical Society of Japan at Nagoya on April 2, 1978.

\section{MATERIALS AND METHODS}

Reagents. All the reagents were purchased from commercial source; egg albumin from E. Merck, cycloheximide from Nakarai Chemicals, Ltd., actinomycin D from Sigma Chemical Co. Radioisotopes were obtained from The Radiochemical Centre (Amersham, England); L-[U-14 C] leucine $(348 \mathrm{mCi} / \mathrm{mmol})$, $\left[\mathrm{Me}-{ }^{3} \mathrm{H}\right]$ thymidine $(47 \mathrm{Ci} / \mathrm{mmol})$ and $\left[5-{ }^{2} \mathrm{H}\right]$ uridine (27 $\mathrm{Ci} / \mathrm{mmol})$.

Animals and feeding experiments. Male Wistar rats* were maintained in an air-conditioned room at $22 \pm 1{ }^{\circ} \mathrm{C}, \mathrm{R} . \mathrm{H} .60 \%$, and were raised on laboratory chow** before the experiments. They, weighing between 180 and $220 \mathrm{~g}$, were starved but allowed water ad libitum for 4 days. In the morning on the 5th day, about half of the animals were freely fed egg albumin or sucrose. About $3 \mathrm{~g}$ portions were moistened with a small amount of water to provide, which aimed to be quickly eaten within an hour. In the germ-free experiments, male rats of Fisher strain were used, which had been inbred at Yakult Research Institute, ${ }^{* * *}$ in a completely sterilized condition throughout. They were maintained by feeding of autoclaved MF diet until the body weight attained to 100 to $120 \mathrm{~g}$. The

* Shizuoka Agricultural Cooperative Association for Laboratory Animals, Hamamatsu, Japan.

** MF type, Oriental Yeast Co.

*** Kunitachi, Tokyo. 
dietary egg albumin had been sterilized by an irradiation at $5 \mathrm{Mrad}$ **** The microbial-free circumstance of animals was verified by the bacteriological inspection of feces. As a conventional group, same strain of rats bred in an opened atmosphere were used.

Preparation of mucosal homogenates. On scheduled times, rats were killed by bleeding the carotid artery under ether anesthesia. The entire small intestine was rapidly removed and the intestinal contents were thoroughly rinsed out with $0.9 \% \mathrm{NaCl}$. The proximal $10 \mathrm{~cm}$ portion of the small intestine was cut off and longitudinally opened. Mucosal tissue was scraped off with a glass slide, then was homogenized with a polytron homogenizer in $0.3 \mathrm{M}$ mannitol solution, and filled up to $40 \mathrm{ml}$ with the same solution. The procedures were performed at $4^{\circ} \mathrm{C}$.

This portion of the small intestine corresponds to whole duodenum and upper part of jejunum, which may contain most of alkaline phosphatase and substantial amounts of other two enzymes.

Enzyme assays. Following methods were used; sucrase, the method by Takesue and Sato ${ }^{4)}$ using $0.1 \mathrm{M}$ sucrose in $0.1 \mathrm{M}$ phosphate buffer at $\mathrm{pH}$ 6.5. Leucine $p$-nitroanilidase, a partially modified method of Saito et al. ${ }^{5)}$ using $1 \mathrm{~mm}$ L-leucine $p$-nitroanilide as a substrate in $80 \mathrm{~mm}$ phosphate buffer at $\mathrm{pH} 7.0$, containing $1 \mathrm{~mm}$ $\mathrm{CoCl}_{2}$. Liberated $p$-nitroaniline was determined according to Goldbarg and Rutenburg. ${ }^{6)}$ Alkaline phosphatase, the method by Hübscher and West ${ }^{7}$ ) using $40 \mathrm{~mm} \beta$-glycerophosphate in $40 \mathrm{~mm}$ diethylamine$\mathrm{HCl}$ buffer at $\mathrm{pH}$ 9.5. Enzyme activities were expressed as $\mu$ moles product per min. per $\mu \mathrm{g} \mathrm{DNA}$.

Analyses. Protein was determined by Lowry's method, ${ }^{8)}$ using bovine serum albumin as a standard. Determination of DNA was followed by Burton's method $^{\text {) }}$ using herring sperm DNA as a standard. Statistical significance of difference was estimated by student's $t$-test.

Experiments with inhibitors. Cycloheximide, dissolved in distilled water $(1 \mathrm{mg} / \mathrm{ml})$, was injected intraperitoneally at the level of $1.5 \mu \mathrm{g}$ per $\mathrm{g}$ body weight. The effect on protein synthesis and DNA synthesis was verified by determining the incorporation of ${ }^{14} \mathrm{C}$-leucine and ${ }^{3} \mathrm{H}$-thymidine, respectively. Five $\mu \mathrm{Ci}$ of $\mathrm{L}_{-}\left[\mathrm{U}-{ }^{14} \mathrm{C}\right]$ leucine $(25 \mu \mathrm{Ci} / \mathrm{ml})$ and $15 \mu \mathrm{Ci}$ of $\left[\mathrm{Me}-{ }^{3} \mathrm{H}\right]$ thymidine $(50 \mu \mathrm{Cl} / \mathrm{ml})$ were intraperitoneally given $30 \mathrm{~min}$ or $60 \mathrm{~min}$ before death. Actinomycin D $(500 \mu \mathrm{g} / \mathrm{ml})$ was injected intraperitoneally at the level of $0.5 \mu \mathrm{g}$ per $\mathrm{g}$ body weight. Inhibition of RNA synthesis was assayed by administering $100 \mu \mathrm{Ci}$ of $\left[5{ }^{3} \mathrm{H}\right]$ uridine $(500 \mu \mathrm{Ci} / \mathrm{ml})$ $30 \mathrm{~min}$ before death. Control rats were simultaneously

**** By courtesy of The Institute of Physical and Chemical Research, Saitama, Japan. injected with $0.9 \% \mathrm{NaCl}$ solution.

Assays of radioactivity. Aliquotes of mucosal homogenate were added to cold $10 \%$ trichloroacetic acid (TCA). The precipitate by centrifugation was washed with $5 \%$ TCA and was counted by the following method of Kawakami and Shimura. ${ }^{10}$ The TCAprecipitate was dissolved in $1 \mathrm{~N} \mathrm{NaOH}$, then added to 15 $\mathrm{ml}$ of liquid scintillator, which was constituted of nonylphenoxypolyethoxyethanol* 7: toluene 3 : PPO $4 \mathrm{~g} /$ liter and finally neutralized by adding $0.5 \mathrm{ml}$ of $2 \mathrm{~N}$ HCl. The dissolved samples were counted in a Aloka LSC-651 liquid scintillation counter. The counting efficiency for ${ }^{14} \mathrm{C}$ and ${ }^{8} \mathrm{H}$ were $52 \%$ and $19 \%$ respectively.

\section{RESULTS}

\section{Time course of brush border enzyme activities}

To confirm the validity for the expression of enzyme activities of mucosal homogenate, the concentration of protein and of DNA was determined under various conditions. As shown in Table $\mathrm{I}$, the amount of protein per $\mathrm{ml}$ homogenate, i.e., per segment, was not changed either $4 \mathrm{hr}$ after feeding of egg albumin or $24 \mathrm{hr}$ after feeding of sucrose, irrespective of cycloheximide treatment. During these time periods, responses of enzyme activities attained to their maximum levels which may be shown in Fig. 2. On the other hand, the amount of DNA per ml homogenate tended to be increased by the injection of cycloheximide. Consequently, protein-DNA ratios were decreased. Moreover, protein content, expressed per DNA, was significantly increased 4 to $8 \mathrm{hr}$ only after protein feeding (Fig. 1). From these results, the amount of DNA rather than that of protein seems to reflect alterations in the intestinal mucosal cells more sensitively.

Figure 2 shows time course of specific activities for three enzymes after feeding of protein or sucrose. The responses by egg albumin were identical for all the enzymes, which may be a reflection of rapid protein synthesis by protein repletion in the starved rats. In contrast, the feeding of sucrose affected sucrase activity alone and the increase was not observed until $8 \mathrm{hr}$, during which time the induction by

* Nonion NS-210, Nippon Oils \& Fats Co. 
Table I. Protein-DNA Ratio in Intestinal Mucosa With oR Without Cycloheximide on Starvation, or after feeding of Egg Albumin or Sucrose.

\begin{tabular}{|c|c|c|c|c|c|c|c|}
\hline Exp. $^{a}$ & Food & & $\begin{array}{l}\text { Cyclo- } \\
\text { heximide }\end{array}$ & $\begin{array}{l}\text { Time } \\
\text { after } \\
\text { feeding }\end{array}$ & Protein & DNA & Protein/DNA \\
\hline & & & & (hr) & $(\mu \mathrm{g} / \mathrm{ml} \mathrm{h}$ & mogenate) & $(\mu \mathrm{g} / \mu \mathrm{g})$ \\
\hline \multirow[t]{2}{*}{$\mathrm{A}$} & Starved & $(3)^{d}$ & - & - & $822 \pm 16^{e}$ & $14.7 \pm 0.9$ & $56.3 \pm 4.3$ \\
\hline & & (3) & + & - & $787 \pm 29$ & $18.6 \pm 1.0^{*}$ & $42.4 \pm 1.0^{*}$ \\
\hline \multirow[t]{5}{*}{ B } & Starved & (4) & - & 0 & $1134 \pm 38$ & $17.1 \pm 0.7$ & $66.4 \pm 0.3$ \\
\hline & Egg albumin ${ }^{b}$ & (4) & - & 4 & $1152 \pm 25$ & $16.3 \pm 1.0$ & $71.6 \pm 3.5$ \\
\hline & & (4) & + & 4 & $1158 \pm 39$ & $20.3 \pm 0.9^{*}$ & $57.1 \pm 1.2^{* *}$ \\
\hline & Sucrose $^{c}$ & (5) & - & 24 & $1178 \pm 31$ & $18.7 \pm 0.5$ & $63.0 \pm 1.3$ \\
\hline & & (5) & + & 24 & $1124 \pm 52$ & $19.5 \pm 1.3$ & $58.1 \pm 1.5^{*}$ \\
\hline
\end{tabular}

a Two experimental groups were treated under same conditions but from different colonies each other.

$b$ Rats were fed egg albumin from 1000 to $1100 \mathrm{hr}$, then were injected intraperitoneally with cycloheximide $(1.5 \mu \mathrm{g} / \mathrm{g}$ b.w.) and were killed at $1400 \mathrm{hr}$.

c Rats were fed sucrose from 1000 to $0700 \mathrm{hr}$ on the next day, then were injected with cycloheximide and were killed at $1000 \mathrm{hr}$ on the next day.

d The number of animals is shown in parentheses.

- Results are given as means \pm SEM.

Significantly different from respective control rats, * $P<0.05 ; * * * 0.01$.

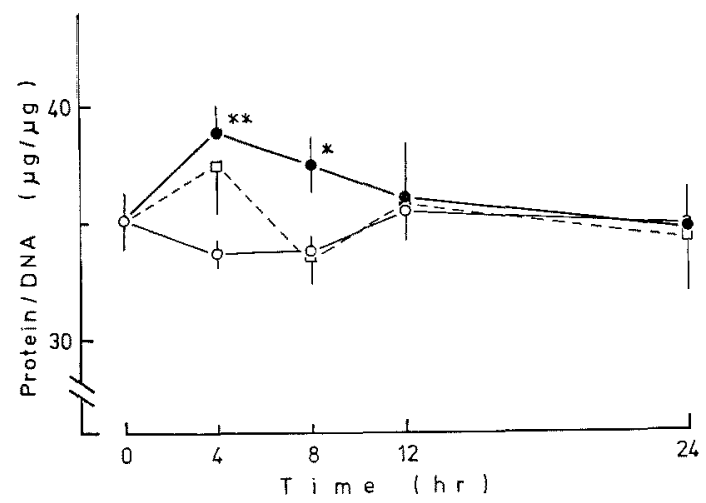

FIG, 1. Change of Protein-DNA Ratio in Intestinal Mucosa after Feeding of Egg Albumin or Sucrose.

Results are plotted as means from three rats with standard errors. Significantly different from corresponding starved rats, $* P<0.05 ; * * P<0.01$.

egg albumin-fed; $\square--\square$, sucrose-fed; $\bigcirc-0$, starved.

protein-feeding had been attained to almost maximum level. However, at $12 \mathrm{hr}$ and thereafter, the sucrase activity began to increase. This delayed induction by dietary sucrose has been reported by several authors. ${ }^{11,(2)}$

\section{Effect of inhibitors}

To clarify whether these changes in enzyme activities were a reflection from net protein synthesis or from other factors affecting enzymes, the treatment with cycloheximide or

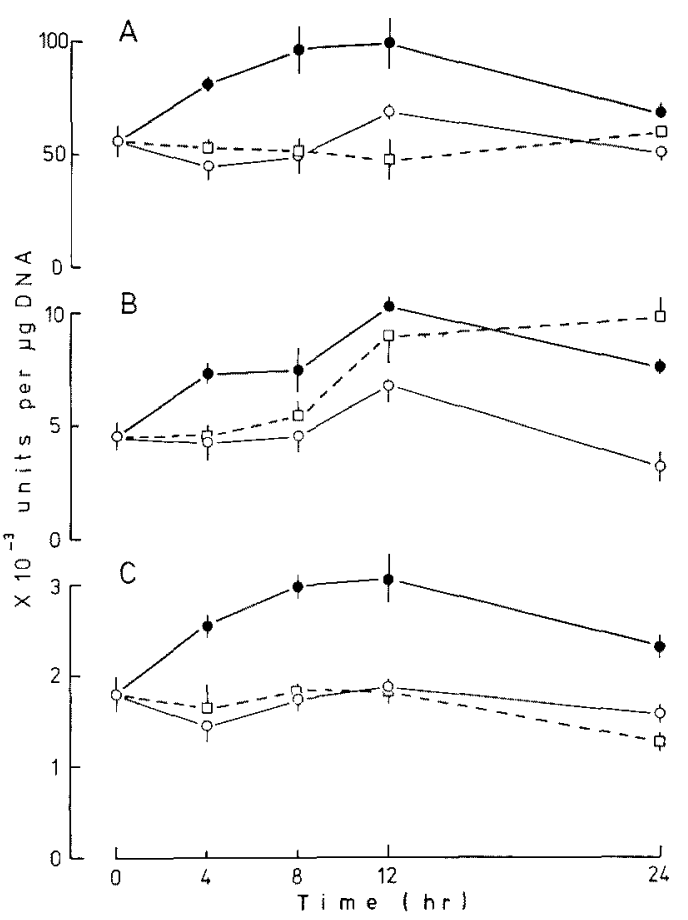

FIG. 2. Time Course of the Activities of Alkaline Phosphatase (A), Sucrase (B), Leucine p-Nitroanilidase (C) after Feeding of Egg Albumin or Sucrose.

See Fig. 1 as to the expressions.

actinomycin $\mathrm{D}$ was implicated in feeding experiments. The injection of cycloheximide, whose dose rapidly inhibited the incorporation 

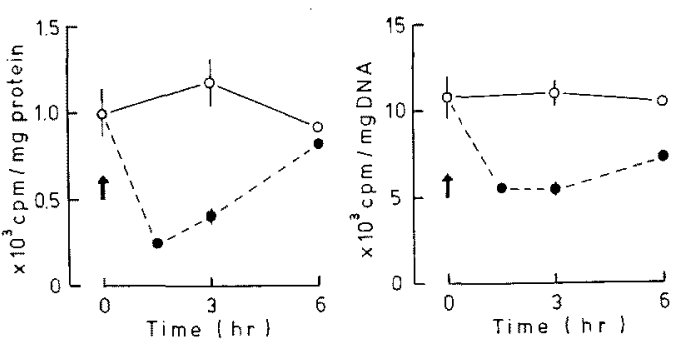

FIG. 3. Effect of Cycloheximide on the Incorporation of ${ }^{14} \mathrm{C}$-Leucine (left) or of ${ }^{3} \mathrm{H}$-Thymidine (right) into Intestinal Mucosa in Starved Rats.

Cycloheximide was injected at the time shown by the arrow. Results are plotted as means from two or three rats (with bar). O-O, control; ---e, cycloheximide.

of ${ }^{14} \mathrm{C}$-leucine and of ${ }^{3} \mathrm{H}$-thymidine (Fig. 3), did not significantly affect protein content, but slightly increased DNA content in starved and in protein-repleted rats (Table I). These results in decreasing DNA synthesis and increasing DNA content may be explained as a temporal increment in cell number of intestinal epithelium, which may be attributed to an inhibition of DNA synthesis at crypts followed by a delayed cell migration into villi. Anyhow, all the enzyme activities from starved rats were equally decreased by $50 \%$ at 3 to $6 \mathrm{hr}$ after injection (Fig. 4), and those induced by egg albumin or by sucrose were also significantly inhibited (Table II).

As shown in Fig. 5, the injection of actino-

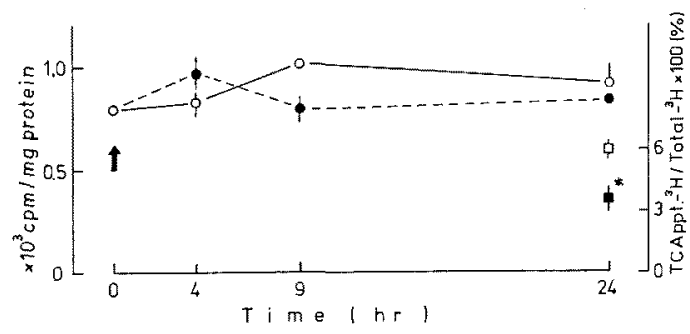

FIG. 5. Effect of Actinomycin D on the Incorporam tion of ${ }^{14} \mathrm{C}$-Leucine and of ${ }^{3} \mathrm{H}$-Uridine into Intestinal Mucosa in Starved Rats.

Actinomycin $\mathrm{D}$ was injected at the time shown by the arrow. Results are plotted as means from two or three rats (with bar). ${ }^{14} \mathrm{C}$-leucine: $\mathrm{O}-\mathrm{O}$, control; ----, actinomycin D. ${ }^{3} \mathrm{H}$-uridine: $\square$, control; actinomycin $\mathrm{D}$.

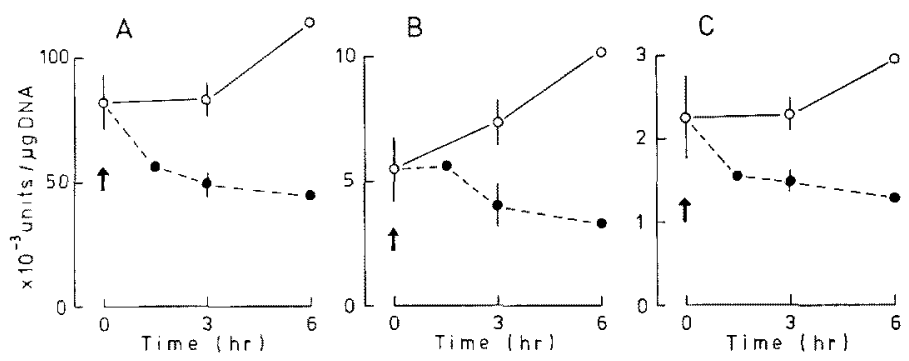

FIG. 4. Effect of Cycloheximide on the Activities of Alkaline Phosphatase (A), Sucrase (B), Leucine $p$-Nitroanilidase (C) in Starved Rats.

See Fig. 3 as to the expressions.

Table II. Effect of Cycloheximide on Intestinal Brush Border Enzyme Activities after Feeding of Egg Albumin or Sucrose

\begin{tabular}{|c|c|c|c|c|c|c|}
\hline \multicolumn{2}{|c|}{ Food } & $\begin{array}{l}\text { Cyclo- } \\
\text { heximide }\end{array}$ & $\begin{array}{l}\text { Time after } \\
\text { feeding }\end{array}$ & $\begin{array}{c}\text { Alkaline } \\
\text { phosphatase }\end{array}$ & Sucrase & $\begin{array}{c}\text { Leucine } \\
p \text {-nitroanilidase }\end{array}$ \\
\hline & & & (hr) & & $\left(\times 10^{-3}\right.$ units $/ \mu \mathrm{g} \mathrm{I}$ & NA) \\
\hline \multirow{2}{*}{ Starved } & (4) & - & 0 & $72 \pm 4$ & $4.75 \pm 0.91$ & $2.76 \pm 0.22$ \\
\hline & (2) & + & 4 & 26 & 2.17 & 1.04 \\
\hline \multirow[t]{2}{*}{ Egg albumin } & (4) & - & 4 & $108 \pm 6$ & $8.40 \pm 0.56$ & $3.85 \pm 0.07$ \\
\hline & (4) & + & 4 & $61 \pm 7^{* *}$ & $5.91 \pm 0.28^{* *}$ & $2.74 \pm 0.23^{* *}$ \\
\hline Starved & (4) & - & 24 & - & $5.22 \pm 0.62$ & - \\
\hline \multirow[t]{2}{*}{ Sucrose } & (5) & - & 24 & - & $13.8 \pm 1.0$ & - \\
\hline & $(5)$ & + & 24 & - & $9.76 \pm 1.29^{*}$ & - \\
\hline
\end{tabular}

The experimental conditions were the same as those in the footnote under Table $\mathbf{I}$. 
Table 11I. EfFect of Actinomycin D on Intestinal Brush Border Enzyme Activities after Feeding of Egg Albumin or Sucrose

\begin{tabular}{|c|c|c|c|c|c|c|}
\hline \multicolumn{2}{|l|}{ Food } & $\begin{array}{l}\text { Actino- } \\
\text { mycin D }\end{array}$ & $\begin{array}{l}\text { Time after } \\
\text { feeding }\end{array}$ & $\begin{array}{c}\text { Alkaline } \\
\text { phosphatase }\end{array}$ & Sucrase & $\begin{array}{c}\text { Leucine } \\
\text { p-nitroanilidase }\end{array}$ \\
\hline & & & (hr) & \multicolumn{3}{|c|}{$\left(\times 10^{-3}\right.$ units $/ \mu \mathrm{g}$ DNA $)$} \\
\hline Starved & (4) & - & 10 & $82.9 \pm 9.5$ & $8.67 \pm 1.30$ & $2.47 \pm 0.23$ \\
\hline \multirow{2}{*}{ Egg albumin ${ }^{\star}$} & $(5)$ & - & 10 & $94.7 \pm 7.5$ & $10.78 \pm 1.11$ & $3.36 \pm 0.17$ \\
\hline & (5) & + & 10 & $66.8 \pm 8.7^{*}$ & $4.94 \pm 1.10^{* *}$ & $1.86 \pm 0.26^{* *}$ \\
\hline Starved & (2) & - & 21 & - & 6.5 & - \\
\hline \multirow[t]{2}{*}{ Sucrose $^{b}$} & (4) & - & 21 & - & $14.1 \pm 1.1$ & - \\
\hline & (4) & + & 21 & - & $2.7 \pm 0.3^{* * *}$ & - \\
\hline
\end{tabular}

a Rats were fed egg albumin from 1000 to $1200 \mathrm{hr}$, then were injected intraperitoneally with actinomycin $\mathrm{D}(0.5 \mu \mathrm{g} / \mathrm{g} \mathrm{b} . \mathrm{w}$.$) and were killed at 2000 \mathrm{hr}$.

b Rats were fed sucrose from 1800 to $2300 \mathrm{hr}$, then were injected with actinomycin D and were killed at $1500 \mathrm{hr}$ on the next day.

See the footnote under Table I. as to other expressions.

mycin $\mathrm{D}$ to starved rats was enough to inhibit ${ }^{3} \mathrm{H}$-uridine incorporation by $40 \%$ at $24 \mathrm{hr}$, but did not affect ${ }^{14} \mathrm{C}$-leucine incorporation at varying times after the actinomycin $D$ treatment. In the same condition, only sucrase activity was significantly inhibited, whereas alkaline phosphatase and leucine $p$-nitroanilidase
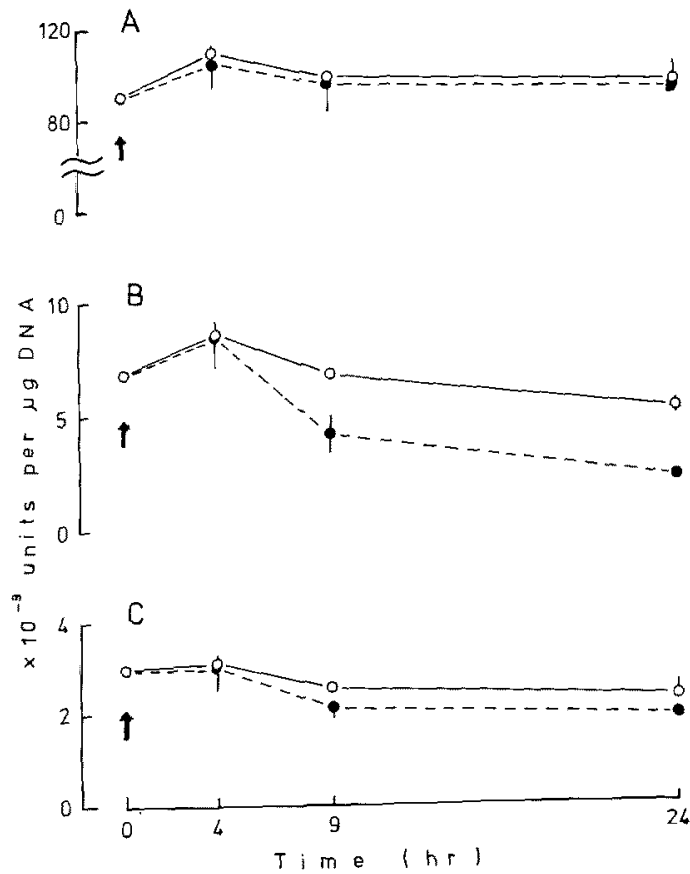

Frg. 6. Effect of Actinomycin D on the Activities of Alkaline Phosphatase (A), Sucrase (B), Leucine $p$ Nitroanilidase $(C)$ in Starved Rats.

See Fig. 5 as to the expressions. were little affected up to $24 \mathrm{hr}$ (Fig. 6). However, in the protein-repleted or sucrose-fed rats all three enzyme activities were depressed to their fasting levels or even to below ones (Table III). The incorporation of ${ }^{3} \mathrm{H}$-uridine in the same preparations seemed not to be inhibited as shown in Table IV.

TABle IV. EFFect of Actinomycin D ON the INCORPORATION OF ${ }^{3} \mathrm{H}$-URIDINE AFTER FEEDING of Egg Albumin or Sucrose

\begin{tabular}{llcc}
\hline \multicolumn{1}{c}{ Food } & & Actinomycin D & Incorporation $^{a}$ \\
Starved & $(4)$ & - & $5.8 \pm 0.3$ \\
Egg albumin & $(5)$ & - & $7.3 \pm 0.6$ \\
& $(5)$ & + & $8.3 \pm 0.3$ \\
Starved & $(2)$ & - & $7.7(7.6 \sim 7.7)^{b}$ \\
Sucrose & $(2)$ & - & $8.9(8.4 \sim 9.3)$ \\
& $(2)$ & + & $10.9(10.9)$ \\
\hline
\end{tabular}

The experimental conditions were the same as those in the footnote under Table III.

a The data are represented as TCAppt. ${ }^{3} \mathrm{H} /$ total${ }^{3} \mathrm{H} \times 100$.

$\checkmark$ The range of the values is given in parentheses. See the footnote under Table I as to other expressions.

\section{Influence of intestinal microflora}

Effect of egg albumin-feeding on starved germ-free rats was examined. As shown in Table $\mathrm{V}$, neither alkaline phosphatase nor sucrase activity increased significantly on egg albumin-feeding, which was different from those in the conventional groups. We did not try to compare absolute values between these 
Table V. Influence of Intestinal Microflora on Alkaline Phosphatase and Sucrase Activities 4 Hr after Egg Albumin-FeEding

\begin{tabular}{rcccc}
\hline & Egg albumin & \multicolumn{2}{c}{$\begin{array}{c}\text { Alkaline } \\
\text { phosphatase }\end{array}$} & Sucrase \\
\hline \multirow{2}{*}{ Animal } & & & $\left(\times 10^{-3}\right.$ units $/ \mu \mathrm{g}$ DNA $)$ \\
Conventional & $(5)^{a}$ & - & $53.2 \pm 6.5^{b}$ & $4.48 \pm 0.67$ \\
Germ-free & $(5)$ & + & $81.0 \pm 7.1^{*}$ & $7.61 \pm 0.47^{* *}$ \\
& $(4)$ & - & $76.8 \pm 4.2$ & $14.1 \pm 0.78$ \\
& $(4)$ & + & $82.3 \pm 8.7$ & $16.6 \pm 1.61$ \\
\hline
\end{tabular}

a The number of animals is shown in parentheses.

$b \quad$ Results are given as means \pm SEM.

Significantly different from respective control rats, ${ }^{*} P<0.05 ;{ }^{* *} P<0.01$.

two groups, since they were supplied from different colonies and were also raised in separate condition. But higher activities in germ-free rats than in conventional rats may be generally observed as a typical appearance in these animals. ${ }^{13}$, The amount of egg albumin consumed by starved germ-free rats was not altered from former experiments.

\section{DISCUSSION}

The mechanism that an enzyme activity of intestinal brush border changes in response to a dietary stimulation has not been fully elucidated. It seems not only due to alterations in the molecular mechanism directly affecting enzyme, but also to the changes in the epithelial cell turnover as a reflection from alterations in mitosis as well as cell migration rate from crypts to villi. In mucosal tissue, DNA synthesis is located in crypts, whereas these enzymes are located in brush border of villi. ${ }^{14}$ Hopper et $a l^{15)}$ have reported that protein depletion or starvation lowered the rate of cell migration in intestinal mucosa, resulting from an elongated cell cycle and a lengthening of the maturation period. In our experiments with 4-day starved rats, cell migration must also be delayed. The treatment with cycloheximide seemed to greatly promote such an effect on cell migration by inhibiting DNA synthesis. Slight but significant rise in DNA content in cycloheximide-treated rats may explain these mechanisms well.

The present study with cycloheximide supports the suggestion by Deren et al. ${ }^{11)}$ that the increase of sucrase activity after feeding of sucrose was due to an increased quantity of enzyme.

On the other hand, our results obtained from actinomycin D treatment were much complicated to be explained. Firstly, sucrase was the only enzyme whose activity was dropped by the antibiotic (Fig. 6). Recently, Kimura et al. ${ }^{121}$ reported similar results that the injection of actinomycin D depressed disaccharidase activities (sucrase and maltase) from the rats fed high sucrose diet, without an effect on leucine aminopeptidase. This unequal effect of actinomycin $\mathrm{D}$ has also been observed by Imondi et $a .^{\left.1{ }^{10}\right)}$ for the cytoplasmic enzymes in intestinal mucosa. These results might be explained as the different stability of respective messenger-RNA species. Secondly, the increased activities in all three enzymes by dietary protein were decreased to the levels less than those in starvation (Table III), but RNA synthesis was not abolished (Table IV). These unusual effects were also observed in sucrosefeeding experiments, which showed the similar results that the treatment of actinomycin $D$ $5 \mathrm{hr}$ after feeding of sucrose drastically depressed sucrase activity at $21 \mathrm{hr}$ (Table III) without changing RNA synthetic activity (Table IV).

Grand et al. ${ }^{17)}$ observed that when rats were fed sucrose-rich diet after having kept on a normal diet for several days, sucrase activity was not inhibited by actinomycin D but rather increased after $24 \mathrm{hr}$. Their results were not agreed with ours using starved rats as a control. The starvation in our studies remarkably 
brought about nonspecific stimulation in protein synthesis by protein repletion, whereas in their experiments the nutritional condition was intact throughout. According to their explanation, actinomycin $\mathrm{D}$ may stimulate intracellular transport of sucrase or lactase from its synthetic site to brush border. They also observed specific effect of sucrose after starvation, which was an almost similar condition as our present experiment except that they used a mixed diet high in sucrose. ${ }^{18)}$ However, the results were contrast between theirs and ours that actinomycin D still enhanced sucrase activity in their homogenate. This discrepancy may partly be explained, if not all, as the difference in the amount of this antibiotic. They used smaller doses $(0.25 \mu \mathrm{g} / \mathrm{g}$ body weight) than ours $(0.5 \mu \mathrm{g} / \mathrm{g}$ body weight $)$.

In this respect, Yamada et al. $^{19}$ ) have reported that amino acid absorption from rat jejunal loops was inhibited by prior treatment of actinomycin $\mathrm{D}(1.0$ or $1.5 \mu \mathrm{g} / \mathrm{g}$ body weight), but with smaller doses $(0.25 \mu \mathrm{g} / \mathrm{g}$ body weight) opposite results were obtained that absorption was rather increased, which may probably be due to the stimulation of corticosteroides secretion by such a small amount used. However, our results showing uniform inhibition for all the enzymes without inhibiting RNA synthetic activity is still difficult to explain. Other mechanism than a direct action of the antibiotic on DNA-directed RNA synthesis may be conceivable.

As to our experiments dealt with relatively short time after a dietary stimulation, intestinal microflora may not have any positive role in protein stimulation to enzyme activities, since both alkaline phosphatase and sucrase activities did not significantly rise $4 \mathrm{hr}$ after protein ingestion (Table $\mathrm{V}$ ). These results may be explained as a relatively slow response of these enzymes in intestinal mucosa of germfree rats. Their responses may be simply shifted to necessitate longer time in such a slower state of the metabolism, or may become insensitive to protein stimulation owing to surplus amount of enzymes in germ-free rats as compared with conventional ones.

Acknowledgment. The authors are indebted to Yakult Research Institute for inbreeding of germ-free rats, and Dr. M. Takahashi for microbial inspections. This work was supported in part by the research project grant No. 310405 from the Ministry of Education, Japan.

\section{REFERENCES}

1) H. Naito and M. Kadowaki, Agric. Biol. Chem., 40, 1435 (1976)

2) Y. Takesue and Y. Nishi, $J$, Biochem., 79, 488 (1976).

3) M. Saito, E. Murakami, T. Nishida, Y. Fujisawa and M. Suda, ibid., 80, S63 (1976).

4) Y. Takesue and R. Sato, ibid., 64, 873 (1968).

5) M. Saito, E. Murakami, T. Nishida, Y. Fujisawa and M. Suda, ibid., 78, 475 (1975).

6) J. A. Goldbarg and A. M. Rutenburg, Cancer, 11, 283 (1958).

7) G. Hübscher and G. R. West, Nature, 205, 799 (1965).

8) O. H. Lowry, N. J. Rosebrough, A. L. Farr and R. J. Randall, J. Biol. Chem., 193, 265 (1951).

9) K. Burton, Biochem. J., 62, 315 (1956).

10) M. Kawakami and K. Shimura, Radioisotopes, 23, 15 (1974).

11) J. J. Deren, S. A. Broitman and N. Zamcheck, J. Clin. Invest., 46, 186 (1967).

12) T. Kimura, A. Seto and A. Yoshida, J. Nutr., 108, 1087 (1978).

13) D. C. Savage, Am. J. Clin. Nutr., 25, 1372 (1972).

14) M. Lipkin, Physiol. Rev., 53, 891 (1973).

15) A. F. Hopper, P. M. Rose and R. W. Wannemacher, Jr., J. Cell Biol. 53, 225 (1972).

16) A. R. Imondi, M. Lipkin and M. E. Balis, J. Biol. Chem., 245, 2194 (1970).

17) R. J. Grand, D. A. Chong and K. J. Isselbacher, Biochim. Biophys. Acta, 261, 341 (1972).

18) R. J. Grand and S. Jaksina, Gastroenterology, 64, 429 (1973).

19) C. Yamada, A. J. Clark and M. E. Swendseid, Science, 158, 129 (1967) 